\title{
Influence of Drugs of Continuous Use on the Sensory Regulation of the Static Balance of Elderly Regular Practitioners of the Pilates Method
}

\section{Influência de Fármacos de Uso Contínuo Sobre a Regulação Sensorial do Equilíbrio Estático de Idosas Praticantes Regulares do Método Pilates}

\author{
Marcelo de Maio Nascimento*a; Deborah Lays Silva de Deus; ${ }^{\mathrm{a}}$; Pâmala Morais Bagano Rios ${ }^{\mathrm{b}}$; \\ Paloma Sthefane Teles Silva ${ }^{\mathrm{d}}$ \\ ${ }^{a}$ Universidade Federal do Vale do São Francisco, Physical Education Course. PE, Brazil.

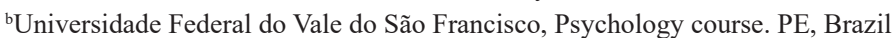 \\ ${ }^{d}$ Universidade de Minas Gerais, Hospital das Clínicas. MG, Brazil. \\ *E-mail: marcelo.nascimento@univasf.edu.br
}

\begin{abstract}
The combination of types of medications can compromise the regulation of body balance in older adults. This study evaluated the effect of continuous use drugs on the sensory regulation of static balance in elderly women who regularly practice the Pilates method with and without a history of falls and estimate the risk of falls in this population. Cross-sectional study, carried out with 94 women (67.12 \pm 4.74 years) practicing Pilates, divided into: non-fallers $(\mathrm{n}=74)$ and fallers $(\mathrm{n}=18)$. Sociodemographic data, comorbidities, medications, and Mini Mental State Examination (MMSE), Falls Efficacy Scale (FES), Confidence in Balance Scale (ABC) were applied. The examination of static balance was performed by the Clinical Test of Sensory Interaction and Balance (CTSIB). The risk of falling was analyzed using an adjusted multiple logistic regression model, while the effect of drugs on falls was estimated by binary regression, results were presented using the odds ratio (OR). The CTSIB test revealed Condition $4(\mathrm{OR}=3.038 ; 95 \% \mathrm{CI}=1.321-15.674)$ and Condition $5(\mathrm{OR}=5.542 ; 95 \% \mathrm{CI}=1.678-18.303)$ as predictors of falls. Drugs showing an effect on fall were $\beta 2$ agonist associated with glucocorticoid $(\mathrm{OR}=0.245 ; 95 \% \mathrm{CI}=1,233-2,400)$, thiazide diuretic $(\mathrm{OR}=0.344 ; 95 \% \mathrm{CI}=1.122-2.234)$, statin $(\mathrm{OR}=0.245 ; 95 \% \mathrm{CI}=1,237-2,338)$, angiotensin II receptor antagonist $(\mathrm{OR}=0,245 ; 95 \% \mathrm{CI}$ $=1,236-2,339)$, beta blocker $(\mathrm{OR}=0,245 ; 95 \% \mathrm{CI}=1,238-2,402)$ and anti-vertigo $(\mathrm{OR}=0,245 ; 95 \% \mathrm{CI}=1.230-2.399)$. Regardless of the history of falls, the risk of falling was present in older adult regular Pilates practitioners. Six different drugs for continuous use showed an effect on falls.
\end{abstract}

Keyword: Accidental Falls. Aging. Women's Health. Accident Consequences.

\section{Resumo}

A combinação de tipos de medicamentos pode comprometer a regulação do equilíbrio corporal de idosos. Este estudo avaliou o efeito de fármacos de uso contínuo sobre a regulação sensorial do equilibrio estático de mulheres idosas praticantes regulares do método Pilates

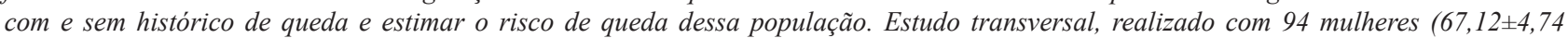
anos) praticantes de Pilates, divididas em: não-caidoras $(n=74)$ e caidoras $(n=18)$. Foram coletados dados sociodemográfico, comorbidades, medicamentos, e aplicado Mini Exame do Estado Mental (MEEM), Falls Efficacy Scale (FES), Escala de Confiança no Equilíbrio (ABC). O exame do equilibrio estático foi realizado pelo Clinical Test of Sensory Interaction and Balance (CTSIB). O risco de queda foi analisado pelo modelo de regressão logística múltipla ajustado, enquanto, que o efeito dos fármacos sobre queda foi estimado pela regressão binária, resultados foram apresentados pelo odds ratio (OR). O teste CTSIB revelou a Condição 4 (OR=3,038; 95\% IC = 1,321-15,674) e Condição $5(O R=5,542 ; 95 \%$ IC $=1,678-18,303)$ como previsora de quedas. As drogas que mostram efeito sobre queda foram agonista $\beta 2$ associada com glicocorticóide $(O R=0,245 ; 95 \% I C=1,233-2,400)$, diurético tiazídico $(O R=0,344 ; 95 \%$ IC $=1,122-2,234)$, estatina (OR=0,245; 95\% IC =1,237-2,338), antagonista do receptor de angiotensina II $(O R=0,245 ; 95 \%$ IC =1,236-2,339), betabloqueador $(O R=0,245 ; 95 \%$ $I C=1,238-2,402)$ e antivertiginoso $(O R=0,245 ; 95 \% I C=1,230-2,399)$. Independente do histórico de quedas, o risco de cair esteve presente em idosas praticantes regulares do Pilates. Seis diferentes medicamentos de uso contínuo mostraram efeito sobre queda.

Palavras-chave: Acidentes por Quedas. Envelhecimento. Saúde da Mulher. Consequências de Acidentes.

\section{Introduction}

Falls are adverse events with significant impact on the health and quality of life of the elderly population. Approximately between 28 and $35 \%$ of individuals aged 65 years or older fall at least once a year ${ }^{1}$, and individuals aged 75 years or older have a drop rate between 32 and $42 \%{ }^{2}$. The fact is also more common among women ${ }^{3}$ because compared to men, they are more exposed to domestic accidents ${ }^{4}$. At an advanced age, falls are considered a public health problem ${ }^{5}$, since they cause injuries, fractures, hospitalization days, limitation of functionality.
Therefore, after the fall, there is a limitation of social contact, which contributes to depressive symptoms ${ }^{6}$.

The causes that cause an elderly person to fall are multifactorial ${ }^{7}$, and there are intrinsic and extrinsic factors. Intrinsic issues are associated with balance performance, gait, vision problems, hearing, fear of falling, and low confidence in balance. While extrinsic factors represent the set of objects scattered in the environment, such as irregular surfaces, slippery surfaces or lighting problems ${ }^{8}$. In the context of falls, the types of medicines consumed by the elderly should also be considered $^{9}$, as well as the association among their substances. 
Some pharmacological classes are responsible for increasing the risk of elderly falls, especially psychotropic drugs ${ }^{10,11}$, $\operatorname{cardiac}^{12}$, opioids and antiepileptic drugs ${ }^{11}$.

Each drug has a profile of adverse reactions, therefore, during treatment one should consider the choice of drugs, considering the interaction effects. The measure can contribute to the rational and safe use of medicines, also minimizing the occurrence of adverse reactions ${ }^{13}$. Polypharmacy is defined as the concomitant use of five or more drugs ${ }^{14}$. In the case of the elderly population, control of polypharmacy is important because it helps to prevent iatrogenic diseases such as fall ${ }^{11}$. Polypharmacy is also related to the increase of drug interactions and antagonistic reactions to the medications themselves, which may suppress pharmacological treatment and intensify, among others, morbidity and mortality ${ }^{15}$.

The direct relationship between the fall of the elderly and medications occurs as well as their adverse effects ${ }^{6,16}$. Some drugs generate sleepiness ${ }^{17}$, hypotension, change muscular tonicity ${ }^{11}$, in addition to compromising the functioning of the visual, vestibular and somatosensory system. In elderly people, changes in vision performance are considered a risk factor for fall. Medications used by elderly individuals such as antipsychotics and tricyclic antidepressants may cause vision to become blurred, generating diplopia ${ }^{18}$. Whereas drugs such as antibiotics, anticonvulsants and anti-inflammatory drugs can cause vertigo ${ }^{19}$.

It is known that physiological aging causes alterations in the functioning of sensory organs ${ }^{20}$, affecting both the capture of postural information and the data transmission to the Central nervous System (CNS). Moreover, when compared to young individuals, elderly individuals present a higher risk of falling. And, knowing that some medications also alter the functioning of receptive inputs, their regular consumption may potentiate deficits in the CNS during the postural information processing. As a result, there may be delays in the postural information processing and in the sending of commands to the extremities of the body, necessary for postural adjustments ${ }^{21}$. This also causes postural imbalance and increased risk of falling ${ }^{22}$.

The goal of this study was to evaluate the effect of continuous use drugs on the sensory regulation of static balance in elderly women who regularly practice the Pilates method with and without a history of falls and estimate the risk of falls in this population.

\section{Material and Methods}

This was a cross-sectional, descriptive and analytical study. The collections were developed between January and March 2019 with members of the Pilates group of the Open University at the third Age (UNATI), linked to the Federal University of Vale do San Francisco (UNIVASF), located in the city of Petrolina-PE. All participants signed the Informed Consent Form (ICF). The study was approved by the Research Ethics on Human Beings Research of UNIVASF (Legal
Opinion number 088832/2017).

\subsection{Participants}

Members of this research regularly participated in Pilates method classes twice a week (60 min.). 94 female individuals were included. The inclusion of only women is justified because $96 \%$ of the members of this project were female. Based on the history of falls (last 12 months), the participants were allocated to the groups: non-fallers $(n=98)$ and fallers $(\mathrm{n}=18)$. The sampling calculation was performed a posteriori using the Software $\mathrm{G}^{*}$ Power 3.1.3, an effect size of $50 \%$ was considered and $\alpha$ mean probability error of 0.50 $,(1-\beta$ probability error $)=0,6153753, \mathrm{DF}=114$, Critical $t=$ 1.6583300 , Noncentrality parameter 1.9498011 was obtained.

Pilates classes were taught by a certified instructor in Pilates method, accompanied by a physical Education student. The physical program consisted of the following set of exercises: the hundred, roll up, single leg circle, single leg stretches, double leg stretches, single straight leg stretches, side kick lift, spine stretch forward, swimming, shoulder bridge and torpedo. According to the Pilates team, planning the degree of difficulty of each sequence of exercises was modified every six meetings, respecting, however, the physical and functional fitness of each participant. As an inclusion criterion, 75\% participation in Pilates activities was adopted over the last six months before the study was carried out and age $\geq 60$ years. Elderly individuals who did not sign the ICF or did not complete all stages of the study were excluded.

\subsection{Procedures}

The investigation comprised three moments. Initially, by means of a questionnaire, sociodemographic data, comorbidities, life habits and history of falls were collected (last 12 months) and the different types of drugs consumed. The anthropometric assessment was carried out with the aid of a mechanical scale of up to $300 \mathrm{~kg}$. Body mass index (BMI) was calculated using the formula: mass $(\mathrm{kg}) /$ height $(\mathrm{m})^{2}$;

In a second moment, the instruments were used: a) Mini Mental State examination(MMSE) ${ }^{23}$ : used for screening low cognition capacity and screening to detect possible Dementia cases. The diagnosis was established by a scoring system: 18 points for illiterate people, 21 for 1-3 years of schooling, 24 for 4-7 years of schooling, and 26 points for people with education over 7 years ; b) A Falls Efficacy Scale (FES) ${ }^{24}$ : used to assess the fear of falling, based on 16 questions, that investigate the individual's degree of confidence to perform different tasks, without falling or losing balance. There are four possible answers: i) I am not worried, ii) a little worried, iii) moderately worried, and iv) very worried. The total score ranges from 16 (absence of worry) to 64 (extreme worry); c) Confidence Scale in Balance $(\mathrm{ABC})^{25}$ : used to assess participants' perception of their confidence in balance. The ABC scale consists of 16 questions with an emphasis 
on individual attitudes during the performance of daily life activities. The scoring system is established by the percentage assigned by the interviewee. Values range from $0 \%$ (no confidence) to $100 \%$ (total confidence).

Finally, with the Clinical Test of Sensory Interaction and Balance(CTSIB) test ${ }^{26}$, the sensory regulation of the static balance was examined. CTSIB is known as Sensory Interaction Test, its purpose is to test the influence of stimuli originating in the visual, somatosensory and vestibular system on the static balance regulation. This is a semi-quantitative evaluation method, since it depends on observing the postural strategies performance ${ }^{27}$. CTSIB consists of six tasks, titled as Intersensory conditions, verified in two different types of bases: i) stable, when tasks are performed on the ground, and ii) unstable, when tasks are performed on a foam (Airex ${ }^{\circledR}$ Balance Pad, 16" x 20" x 2-1/2"). The test instruction consists of asking the individual to remain in each condition for 30 seconds in the orthostatic position, feet joined, arms along the body, being instructed not to move the upper limbs, heels and feet to compensate for instability. Three tasks are performed on each of these bases: i) stationary subject with eyes open, ii) standing with eyes closed, and iii) standing with visual conflict, so the subject dresses over the head with a hood consisting of a Japanese flashlight adapted ${ }^{26}$.

During the evaluation, participants were allowed a single attempt for each of the six conditions of the CTSIB. According to Shumway-Cook and Horak ${ }^{26}$, there are two ways to interpret the results of the CTSIB sensorial performance. The first is for stay time in the requested position $(<30$ seconds $=$ abnormal and $\geq 30$ seconds $=$ normal). The second form is the subjective evaluation, performed by observing the degree of postural oscillation. A subjective system with the following score was adopted for evaluation: 1 = minimum oscillation, 2 = light oscillation, 3 = moderate oscillation and, $4=$ fall. Therefore, to facilitate data processing, the scores were grouped in a dichotomous manner. Thus, scores 1 and 2 formed the category of normal postural control (classification 1), while results 3 and 4 were assumed as abnormal postural control (classification 2), considered as risk for fall.

\subsection{Statistical Procedures}

Data on types of medicines were initially tabulated and organized in excel program and after being treated in a statistical program. Shapiro-Wilk test was used to verify the data normality. Nominal variables were analyzed using the Chi-square test, in the presence of values lower than five, Fisher's exact test was applied. The Student's t-test for independent samples was used to determine the significance levels among the comparisons of the performance of the faller and non-faller group in the six tasks of the CTSIB test. Considering that the regulation of the participants' postural control had already been favored by the practice of regular physical exercise and the use of medications was continuous, the independent variables (1) static balance and (2) medications were not manipulated. Through the multivariate linear regression analysis, it was identified which of the six conditions of the CTSIB test (dependent variable) would be fall predictors (dependent variable), therefore the magnitude of the effect of the types of medication on the balance sensory regulation was established, only the variables that indicated significance levels in the univariate model $(p \leq 0,020)$ were considered for the calculation. The insertion order was from the highest to the smallest (forward model), respecting the magnitude of the Spearman correlation coefficient. Whereas, the effects of medicines on falls were calculated by binary logistic regression. Odds ratios (OR, 95\% CI) were used to present the results. The data were processed at the statistic Program SPSS, version 22.0. The significance level established was $\mathrm{p}<0.050$.

\section{Results and Discussion}

94 women $(67.12 \pm 4.74$ years $)$ who practice physical exercises regularly participated in the study (Table 1). Of these, $83 \%(78 / 94)$ did not present a history of falls, whereas $17 \%(16 / 94)$ were fallers. $72.3 \%(68 / 94)$ of the sample was composed of sexagenarians. Among the group with a history of falls, 68.8\% (11/16) were sexagenarian and 6.3\% (5/16) were septuagenarian $(p>0.050)$. No statistically significant result was found for BMI ( $>00.050)$. The mean time of weekly practice of physical exercise ranged from 18 to 24 months ( $p=$ 0.132). Among the comorbidities only Arterial Hypertension presented significance levels $(p=0.032)$. The MMSE instrument attests to the health mental state maintained for both groups $(\mathrm{p}=0.404)$. Regarding the confidence in balance $(\mathrm{ABC})$, the non-faller group presented a higher score $(\mathrm{p}=$ 0.007), while the fear of falling (FES) was higher among the members of the faller group $(p=0.016)$ for the scale of fear of falls and confidence in balance.

Table 1 - Key characteristics of the population evaluated

\begin{tabular}{|l|c|c|c|}
\hline \multicolumn{1}{|c|}{ Variables } & Non-fallers $(\mathbf{n}=\mathbf{7 8})$ & Fallers $(\mathbf{n}=\mathbf{1 6})$ & $\mathbf{p}$ \\
\hline Age & $67.15 \pm 4.52$ & $66.94 \pm 5.85$ & 0.890 \\
60-69 years (f\%) & $57(73.1)$ & $11(68.8)$ & \\
70-79 years (f \%) & $21(26.9)$ & $5(6.3)$ & \\
\hline Schooling & $1(1.3)$ & $2(12.5)$ & 0.118 \\
Illiterate & $18(23.1)$ & $3(6.3)$ & \\
0-3 years & $29(37.2)$ & $7(43.8)$ & \\
4-8 years & $30(38.5)$ & $6(37.5)$ & \\
$>8$ years & & & \\
\hline
\end{tabular}




\begin{tabular}{|c|c|c|c|}
\hline Variables & Non-fallers $(n=78)$ & Fallers $(n=16)$ & $\mathbf{p}$ \\
\hline $\begin{array}{l}\text { Income } \\
0-1 \mathrm{SM} \\
2-3 \mathrm{SM} \\
4-5 \mathrm{SM} \\
>5 \mathrm{SM}\end{array}$ & $\begin{array}{c}11(14.1) \\
42(53.8) \\
16(20.5) \\
9(11.5)\end{array}$ & $\begin{array}{c}5(31.3) \\
5(31.3) \\
5(31.3) \\
1(6.3)\end{array}$ & 0.518 \\
\hline Mass (kg) & $65.88 \pm 11.49$ & $63.11 \pm 10.08$ & 0.340 \\
\hline Height $(\mathrm{cm})$ & $150.00 \pm 0.06$ & $149.00 \pm 0.03$ & 0.309 \\
\hline $\mathrm{CA}$ & $90.51 \pm 14.06$ & $90.66 \pm 9.04$ & 0.955 \\
\hline BMI $\left(\mathrm{Kg} / \mathrm{h}^{2}\right)$ & $30.56 \pm 23.51$ & $28.21 \pm 4.50$ & 0.418 \\
\hline Falls & ------- & $1.54 \pm 0.22$ & 0.999 \\
\hline Exercise time (months) & $26.24 \pm 6.32$ & $25.74 \pm 4.24$ & 0.132 \\
\hline Medications & $2.38 \pm 1.31$ & $2.35 \pm 1.67$ & 0.940 \\
\hline $\begin{array}{l}\text { Polypharmacy (f\%) } \\
(\geq 5 \text { medications) }\end{array}$ & $5(6 \%)$ & $6(37 \%)$ & 0.527 \\
\hline Smoking (f\%) & $2(2 \%)$ & $1(6 \%)$ & 0.988 \\
\hline Heavy drinking (f\%) & ------ & ------ & ----- \\
\hline $\begin{array}{l}\text { Hypertension } \\
\text { Yes }(\mathrm{f} \%) \\
\text { No }(\mathrm{f} \%)\end{array}$ & $\begin{array}{l}36(46.2) \\
42(53.8)\end{array}$ & $\begin{array}{l}12(75.0) \\
4(25.0) \\
\end{array}$ & 0.032 \\
\hline $\begin{array}{l}\text { Diabetes } \\
\text { Yes }(\mathrm{f} \%) \\
\text { No }(\mathrm{f} \%)\end{array}$ & $\begin{array}{l}14(17.9) \\
64(82.1)\end{array}$ & $\begin{array}{c}2(12.5) \\
14(87.5)\end{array}$ & 0.457 \\
\hline $\begin{array}{l}\text { Vision } \\
\text { Yes (f\%) } \\
\text { No }(\mathrm{f} \%)\end{array}$ & $\begin{array}{l}60(76.9) \\
18(32.1)\end{array}$ & $\begin{array}{l}12(75.0) \\
4(25.0)\end{array}$ & 0.526 \\
\hline $\begin{array}{l}\text { Hearing } \\
\text { Yes }(\mathrm{f} \%) \\
\text { No }(\mathrm{f} \%)\end{array}$ & $\begin{array}{c}5(6.4) \\
72(92.3) \\
\end{array}$ & $\begin{array}{l}7(43.8) \\
9(56.3) \\
\end{array}$ & 0.638 \\
\hline $\begin{array}{l}\text { Labyrinthitis } \\
\text { Yes }(\mathrm{f} \%) \\
\text { No }(\mathrm{f} \%)\end{array}$ & $\begin{array}{l}14(17.9) \\
64(82.1)\end{array}$ & $\begin{array}{c}5(31.3) \\
11(68.8)\end{array}$ & 0.547 \\
\hline $\begin{array}{l}\text { Dizziness } \\
\text { Yes (f\%) } \\
\text { No }(\mathrm{f} \%)\end{array}$ & $\begin{array}{l}27(34.6) \\
51(65.4)\end{array}$ & $\begin{array}{l}8(50.0) \\
8(50.0)\end{array}$ & 0.190 \\
\hline $\begin{array}{l}\text { Osteoporosis } \\
\text { Yes }(\mathrm{f} \%) \\
\text { No }(\mathrm{f} \%)\end{array}$ & $\begin{array}{l}18(23.1) \\
60(76.9)\end{array}$ & $\begin{array}{c}3(18.8) \\
13(81.3)\end{array}$ & 0.497 \\
\hline $\begin{array}{l}\text { Rheumatism } \\
\text { Yes (f\%) } \\
\text { No (f\%) }\end{array}$ & $\begin{array}{l}21(26.9) \\
57(73.1)\end{array}$ & $\begin{array}{c}6(37.5) \\
10(62.5)\end{array}$ & 0.285 \\
\hline MMSE & $24.53 \pm 2.65$ & $23.80 \pm 3.07$ & 0.404 \\
\hline FES & $23.53 \pm 6.13$ & $25.53 \pm 5.07$ & 0.050 \\
\hline $\mathrm{ABC}$ & $79.05 \pm 16.51$ & $69.13 \pm 14.92$ & $\mathbf{0 . 0 0 7}$ \\
\hline
\end{tabular}

CA: Abdominal Circumference; BMI: Body mass index; MMSE: Mini Mental State Examination; EDG: Geriatric Depression Scale; FES-1: International Falls Efficiency Scale; ABC: Balance Confidence Scale; SM: Minimum wage.

Source: Research data.

Figure 1 shows the participants' performance in the six conditions of the CTSIB test. The Mann Whitney T test showed significance for Condition $4(\mathrm{t}=-2.641 ; \mathrm{p}=0.010)$, and Condition $5(\mathrm{t}=-2.324 ; \mathrm{p}=0.022)$. According to the analysis, comparatively, the best sensory performance of the static balance was indicated by elderly without a history of fall. An interesting finding was that, regardless of the history of falls, the sensory control deficit (neuromotor interference) was more evident in condition 5 (eyes closed on unstable basis) and condition 6 (visual conflict on unstable basis) (Figure 1).

Figure 1- Normal and abnormal performance results of both groups under the six conditions of CTSIB test
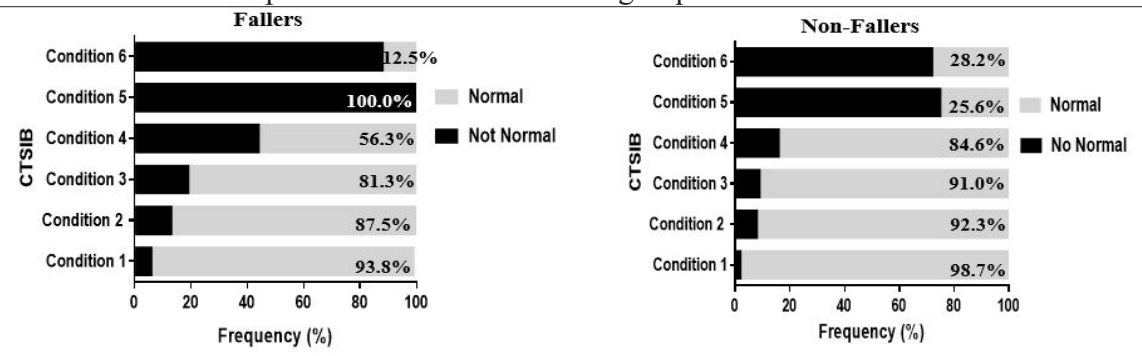

CTSIB: Clinical Test of Sensory Interaction and Balance: Condition 1: Stable base, eyes open; Condition 2: Stable base, eyes closed; Condition 3: Stable base with visual conflict; Condition 4: Unstable base, eyes open; Condition 5: Unstable base, eyes closed; Condition 6: Unstable base with visual conflict.

Source: Research data 
Table 2 shows the results of the adjusted multiple linear regression model for the medications considered to be fall predictors. For the univariate analysis, only drugs with $\mathrm{p}$ value $\leq 0.020$ were included. The model obtained was statistically significant $\left[\mathrm{X}^{2}(1)=27.889 ; \mathrm{p}=0.001 ; \mathrm{R}^{2}{ }_{\text {Negelkerke }}\right.$ $=0.429]$. Of the eight drugs included in the analysis, six indicated a significant effect: Formoterol + budesonide, one agonist $\beta 2$ glucocorticoid $(\beta=0.245 ; \mathrm{t}=2.927 ; \mathrm{p}=0.004)$; Chlortalidone, a thiazide diuretic $(\beta=0.344 ; \mathrm{t}=4.116 ; \mathrm{p}=$ $0.000)$; Atorvastatin, a statin $(\beta=0.245 ; \mathrm{t}=2.927 ; \mathrm{p}=0.002)$; Candesartan an Angiotensin II conversion enzyme inhibitor $(\beta=0.245 ; \mathrm{t}=2.927 ; \mathrm{p}=0.005) ;$ Nebivolol a beta-blocker $(\beta$ $=0.245 ; \mathrm{t}=2.927 ; \mathrm{p}=0.003) ;$ and Betahistine, an anti-vertigo $(\beta=0.245 ; \mathrm{t}=2.927 ; \mathrm{p}=0.002)$.

Table 2 - Results of the adjusted multiple linear regression model for the medications considered to be fall predictors

\begin{tabular}{|l|c|c|c|}
\hline Medications & B & OR (95\%) & p \\
\hline $\begin{array}{l}\text { Formoterol }+ \\
\text { budesonide }\end{array}$ & 0.897 & $0.245(1.233-2.400)$ & 0.004 \\
\hline Chlortalidone & 0.796 & $0.344(1.122-2.234)$ & 0.000 \\
\hline Atorvastatin & 0.897 & $0.245(1.237-2.338)$ & 0.004 \\
\hline Candesartan & 0.897 & $0.245(1.236-2.339)$ & 0.004 \\
\hline Nebivolol & 0.897 & $0.245(1.238-2.402)$ & 0.004 \\
\hline Betahistine & 0.897 & $0.245(1.230-2.399)$ & 0.004 \\
\hline
\end{tabular}

Table 3 shows the results of the regression model that included the participants' performance in CTSIB test. For the calculation of the univariate analysis, only drugs with $\mathrm{p}$ value $\leq 0.020$ were considered. The model obtained was statistically significant $\left[\mathrm{X}^{2}(1)=9.426 ; \mathrm{p}=0.002 ; \mathrm{R}^{2}{ }_{\text {Negelkerke }}\right.$ $=248]$. Among the six conditions of CTSIB, only two were identified as significant fall predictors: CTSIB $4(\mathrm{OR}=3.038$; IC $95 \%=1.321-15.674 ; \mathrm{p}=0.004)$, and CTSIB $5(\mathrm{OR}=$ 5.542; IC $95 \%=1.678-18.303 ; p=0.003)$.

Table 3 - Results of the regression model of CTSIB balance sensory test in relation to the drugs used

\begin{tabular}{|l|c|c|c|}
\hline Variable & B & OR (95\%) & p \\
\hline CTSIB 4 & 1.598 & $3.308(1.321-15.674)$ & 0.004 \\
\hline CTSIB 5 & 1.712 & $5.542(1.678-18.303)$ & 0.003 \\
\hline
\end{tabular}

Source: Research data.

According to the clinical examination of the sensory postural control inputs, performed by the CTSIB test (Figure 1 ), fallers and non-fallers indicated performance classified as normal, since their uses under conditions 1, 2 and 3 of CTSIB were higher than $80 \%$. Therefore, when the three static balance adjustment systems were evaluated on the stable basis with the eyes open, closed and with partial obstruction, the risk for fall was low. On the other hand, when the participants were submitted to the same tasks on the unstable basis (condition 4, 5 and 6), the sensory systems responsible for organizing the postural data were observed to be compromised.

Elderly fallers pointed to a deficit of $100 \%$ in condition 5 of the CTSIB test and $87.5 \%$ in condition 6 , while members of the group without a history of fall indicated a deficit of $74.4 \%$ in condition 5 , and a deficit of $71.8 \%$ in condition 6 . According to the odds ratio (OR), the conditions 4 and 5 of the CTSIB test showed an increase of $230 \%$ and $454 \%$ respectively on the chance to fall. The finding is important, because it warned that regardless of the participants' history of fall in this study, and it is worth highlighting, that they were regular physical exercises practitioners, the sensory system responsible for the static balance regulation presented deficits.

In the context of the elderly fall, the evaluation of the fear of falling (FES scale) and the balance confidence (ABC scale) are important because these perceptions may restrict the realization of ADLs (activities of daily life), affecting the individual's autonomy and quality of $\operatorname{life}^{28}$. Despite the fact that the members of the faller group indicated a lower confidence index in the balance than non-fallers, both groups indicated a low concern with a fall (score between 23-25 points of a total of 69 points). The results showed a lack of concern for this population with falls. The literature points out that the fact may increase the risk of accidents due to attitudes of imprudence and, therefore, greater exposure to the danger of falling ${ }^{29}$.

In the case of self-report on hearing problems, labyrinthitis and dizziness, a prevalence was observed for members of the group with a history of falls $(\mathrm{p}>0.050)$. Literature points out that vestibulopathies have vertigo and visual disorders as symptoms, reflecting on gait and body balance performance ${ }^{19}$. Elderly patients in the present study used the anti-vertigo Betahistine $(p<0.050)$. Tsukamoto and colleagues ${ }^{30}$ found among the elderly that anti-vertigo drugs can negatively affect the postural balance.

It is known that, in general, the elderly population is user of a high number of drugs and that some substances have adverse effects that can increase the risk of falls ${ }^{10,12}$, especially when the individual presents comorbidities ${ }^{11}$. We found statistically significant results for self-reported comorbidities, such as arterial hypertension, which showed a prevalence of $75 \%$ for the faller group. The finding serves as an alert for adverse effects caused by antihypertensive drugs, including orthostatic hypotension, syncope and dizziness ${ }^{31,32}$.

Six out of 70 types of drugs identified indicated a significant effect on falls. Of these, three drugs (Chlortalidone, Candesartan and Nebivolol) had significant implications for conditions 4, 5 and 6 of the CTSIB test, indicating an increase in the chance (OR) of falling between $65-75 \%$. Chlortalidone is a thiazide diuretic used to treat hypertension that can cause orthostatic hypotension. Its action inhibits sodium and chloride import in the distal convoluted tubule, reducing sodium and water reabsorption, with consequent depletion of plasma volume ${ }^{33}$. The literature reports cases of elderly people who consumed this class of drugs and presented fall events right in the first weeks of treatment.

Although there are no evidences to determine the 
association between Atorvastatin and Candesartan with the fall of elderly, our analysis observed the fact. Atorvastatin is used to treat hypercholesterolemia, reducing low-density lipoprotein (LDL) levels in blood ${ }^{35}$. One possible explanation for its significant association with fall is that statins present adverse reactions such as myalgia, myopathy and myonecrosis that can cause muscle weakness that is a risk for falls. Candesartan acts as an inhibitor of the angiotensin II converting enzyme, it is used in the treatment of heart failure and arterial hypertension ${ }^{34}$, however, studies are still needed to prove the relationship between this class of drugs and falls in the elderly population ${ }^{12}$.

A drug that showed association with the condition 6 of the CTSIB test was Nebivolol, considered a beta blocker. Nebivolol has adverse reactions that can lead elderly people to fall, such as orthostatic hypotension, dizziness, bradycardia and fatigue ${ }^{34}$. Its hypotensive action comes from the reduction of the activity of the renin-angiotensin-aldosterone system caused by the $\beta 1$ receptor blockade in the juxtapoclarular renal cells. Nebivolol can also cause orthostatic hypotension in response to changes induced by intravascular volume severity due to negative inotropic and chronotropic effects of $\beta 1$ blockers $^{36}$. All of this reduces the capacity of the heart to increase heart rate and cardiac output, increasing the risk of falls $^{33}$. For this reason, it is advisable for elderly individuals to remain physically active, since physical exercise acts as an effective strategy to improve and maintain adjusted cardiovascular function and functional parameters ${ }^{37}$.

The association of $\beta 2$ agonists with glucocorticoids is widely used in the treatment of respiratory diseases such as asthma and COPD (Chronic Obstructive Pulmonary Disease). There are no evidences to justify an increase in the risk of falls due to the use of these drugs. However, it is known that the prolonged use of glucocorticoids in the treatment of chronic inflammatory diseases may cause adverse reactions, such as changes in bone structure due to reduced mineral density, another problem is loss of muscle mass. These transformations may compromise the balance, increasing the risk of falls, which may generate fractures ${ }^{38,39}$.

This study is considered to have limitations. First, because the cross-sectional design does not allow us to explore the temporality of the associations found. Thus, it was not possible to determine whether the relationships established for the increase of the risk of falls resulting from the deficit in sensory regulation of balance were caused by the use of medications. Second, it was also not possible to infer whether changes in the body balance regulation system were already present even before the beginning of the drugs consumption. Third, it should be considered that falls are multifactor events (gait speed, extrinsic factors), therefore, they cannot be explained solely by the examination of static balance, drug consumption, fear of falling and confidence in balance. Fourth, data on visual and auditory system deficits were selfreported and not obtained by qualified laboratory tests, based on medical report.

\section{Conclusion}

With aging, vestibular, visual and somatosensory systems suffer alterations, causing dysfunctions in their receptive inlets. Due to that, the CNS is not able to integrate postural data coming from the peripheral sensory regions. Thus, the body of elderly individuals can generate distortion during the reception and transmission of information, preventing balance from being restored in a timely manner. In the present study, the effect of six drugs of continuous use was checked on the static balance performance, as well as reports on vision and hearing problems. Therefore, it is concluded to be important that elderly people have regular medical follow-up to check for the drugs of continuous use. In addition to carrying out periodic tests to examine the function of the regulatory mechanisms of the sensory system.

In the present study, the static balance examination pointed to a risk of falling regardless of the history of falls of the population assessed, especially in unstable baseline situations with eyes open and closed. Our results warn to the natural and gradual changes in the balance sensory regulation system even in elderly individuals who practice the Pilates method. Another issue to consider is the rational use of medications, especially those highlighted in this study as responsible for increasing the risk of falls. In order to deepen and qualify the understanding of the findings of the present investigation, it is advisable to perform future studies with a prospective design, with longitudinal follow-up.

\section{References}

1. Mcmullan II, Mcdonough SM, Tully MA, Cupples M, Casson $\mathrm{K}$, Bunting BP. The association between balance and freeliving physical activity in an older community-dwelling adult population: a systematic review and meta-analysis. BMC Public Health 2018;18(1):431. doi:doi.org/10.1186/s12889018-5265-4

2. Maranesi E, Merlo A, Fioretti S, Zemp DD, Campanini I, Quadri P. A statistical approach to discriminate between nonfallers, rare fallers and frequent fallers in older adults based on posturographic data. Clin Biomech 2016;32:8-13. doi: 10.1016/j.clinbiomech.2015.12.009

3. Kalache A. Relatório global da OMS sobre prevenção de quedas na velhice. Who Libr Cat data 2007;1(1):1-64.

4. Khanuja K, Joki J, Bachmann G, Cuccurullo S. Gait and balance in the aging population: Fall prevention using innovation and technology. Maturitas 2018;110:51-6. doi: 10.1016/j.maturitas.2018.01.021

5. Florence CS, Bergen G, Atherly A, Burns E, Stevens J, Drake C. Medical costs of fatal and nonfatal falls in older adults. Am Geriatr Soc 2018;66(4):693-8. doi: 10.1111/jgs.15304

6. Montali F, Campaniello G, Benatti M, Rastelli G, Pedrazzoni M, Cervellin G. Impact of different drug classes on clinical severity of falls in an elderly population: Epidemiological survey in a trauma center. J Clin Gerontol Geriatr 2015;6(2):63-7. doi: 10.1016/j.jcgg.2015.03.002

7. Gale CR, Cooper C, Sayer A. Prevalence and risk factors for 
falls in older men and women: the english longitudinal study of ageing. Age Ageing 2016;45(6):789-94. doi: 10.1093/ ageing/afw129

8. Clemson L, Stark S, Pighills A, Torgerson DJ, Sherrington C, Lamb SE. Environmental interventions for preventing falls in older people living in the community. Cochrane Database Syst Rev 2019;(2). doi: 10.1002/14651858.CD007146.pub2

9. Helgadóttir B, Laflamme L, Monárrez-Espino J, Möller J. Medication and fall injury in the elderly population; do individual demographics, health status and lifestyle matter? BMC Geriatr 2014;14(1):92. doi: 10.1186/1471-2318-14-92

10. Borja-Oliveira CR, Assato CP. Psicofármarmacos potencialmente inapropiado para idoso. Estud Interdic Envelhec 2015;20(3):687-701.

11. Seppala LJ, van de Glind EMM, Daams JG. Fall-RiskIncreasing Drugs: A Systematic Review and Meta-analysis: III. Others. J Am Med Dir Assoc 2018;19(4). doi: 10.1016/j. jamda.2017.12.099

12. de Vries M, Seppala LJ, Daams JG, et al. Fall-RiskIncreasing Drugs: A Systematic Review and Meta-Analysis: I. Cardiovascular Drugs. J Am Med Dir Assoc 2018;19(4). doi: 10.1016/j.jamda.2017.12.013

13. Lima TJV de, Garbin CAS, Araújo PC, Garbin AJÍ, Rovida TAS, Saliba O. Reações adversas a medicamentos entre idosos institucionalizados: prevalência e fatores associados. Arch Heal Investig 2017;6(3):129-35. doi:10.21270/archi. v6i3.192114.

14. Marques PP, Assumpção D, Rezende R, Neri AL, Francisco PMSB. Polifarmácia em idosos comunitários: resultados do estudo Fibra. Rev Bras Geriatr Gerontol 2019;22(5):e190118.

15. Palmer K, Villani ER, Vetrano DL, et al. Association of polypharmacy and hyperpolypharmacy with frailty states: a systematic review and meta-analysis. Eur Geriatr Med 2019;10(1):9-36. doi:10.1007/s41999-018-0124-5

16. Woolcott. Meta-analysis of the Impact of 9 Medication Classes on Falls in Elderly Persons. Arch Intern Med 2010;170(5):477. doi: 10.1001/archinternmed.2009.510

17. Tyagi S, Perera S, Brach JS. Balance and mobility in community-dwelling older adults: effect of daytime sleepiness. J Am Geriatr Soc 2017;65(5):1019-25. doi: 10.1111/jgs. 14735

18. Reed-Jones RJ, Solis GR, Lawson KA, Loya AM, Cude-Islas D, Berger CS. Vision and falls: A multidisciplinary review of the contributions of visual impairment to falls among older adults. Maturitas 2013;75(1):22-8. doi: 10.1016/j. maturitas.2013.01.019

19. Paulino CA, Doná F, Aprile MR. Ocorrência de queixas vestibulares e uso de medicamentos em adultos. Rev Equilíbrio Corpor Saúde 2013;5(2):43-52.

20. Cavazzana A, Röhrborn A, Garthus-Niegel S, Larsson M, Hummel T, Croy I. Sensory-specific impairment among older people. An investigation using both sensory thresholds and subjective measures across the five senses. PLoS One 2018;13(8):e0202969. doi: 10.1371/journal.pone.0202969

21. Fasano A, Plotnik M, Bove F, Berardelli A. The neurobiology of falls. Neurol Sci 2012;33(6):1215-23. doi:10.1007/s10072012-1126-6

22. Leme GLM, Carvalho IF de, Scheicher ME. Melhora do equilíbrio postural em mulheres idosas com o uso de informação sensorial adicional. Fisioter Pesq 2017;24(1):6873. doi: 10.1590/1809-2950/16753224012017
23. Bertolucci PHF, Brucki SMD, Campacci SR JY. O MiniExame do Estado Mental em uma população geral. Impacto da escolaridade. Arq Neuropsiquiatr 1994;52(1):1-7. doi: 10.1590/S0004-282X199400010000

24. Camargos FFO, Dias RC, Dias JMD FM. Adaptação transcultural e avaliação das propriedades psicométricas da Falls Efficacy Scale - International em idosos brasileiros (FES-I-BRASIL). Rev Bras Fisioter 2010;14(3):237-43. doi: 10.1590/S1413-35552010000300010

25. Marques AP, Mendes YC, Taddei U, Pereira CAB AA. Brazilian-Portuguese translation and cross cultural adaptation of the activities-specific balance confidence (ABC) scale. Braz J Phys Ther 2013;17(2):170-7. doi: 10.1590/S141335552012005000072

26. Shumway-Cook A, Horak F. Assessing the influence of sensory interaction of balance. Phys Ther 1986;66(10):154850. doi: $10.2522 / \mathrm{ptj} .20080227$

27. Do Nascimento BN, Duarte BV, Antonini DG, Borges SM. Risco para quedas em idosos da comunidade: relação entre tendência referida e susceptibilidade para quedas com o uso do teste clínico de interação sensorial e equilíbrio. Rev Soc Bras Clin Méd 2009;7(2):95-99.

28. Aibar-Almazán A, Martínez-Amat A, Cruz-Díaz D. Effects of Pilates on fall risk factors in community-dwelling elderly women: a randomized, controlled trial. Eur J Sport Sci 2019:1-9. doi: 10.1080/17461391.2019.1595739

29. Kumar A, Carpenter H, Morris R, Iliffe S, Kendrick D. Which factors are associated with fear of falling in communitydwelling older people? Age Ageing 2014;43(1):76-84. doi: 10.1093/ageing/aft154

30. Tsukamoto HF, Costa VSP, Silva Júnior RA, Pelosi GG, Marchiori LLM, Fernandes KBP. Influência do tratamento com fármacos antivertiginosos sobre o equilíbrio postural e qualidade de vida de indivíduos com queixas de tontura. Rev CEFAC 2015;17(5):1394-402. doi: 10.1590/19820216201517516714

31. Juraschek SP, Daya N, Appel LJ. Orthostatic hypotension in middle-age and risk of falls. Am J Hypertens 2017;30(2):18895. doi: 10.1093/ajh/hpw108

32. Margolis KL, Buchner DM, LaMonte MJ. Hypertension Treatment and Control and Risk of Falls in Older Women. J Am Geriatr Soc 2019;67(4):726-33. doi: 10.1111/jgs.15732

33. Juraschek SP, Appel LJ, Miller ER, Mukamal KJ, Lipsitz LA. Hypertension treatment effects on orthostatic hypotension and its relationship with cardiovascula disease. Hypertension 2018;72(4):986-93. doi: 10.1161/ HYPERTENSIONAHA.118.11337

34. Glab KL, Wooding FGG, Tuiskula KA. Medication-related falls in the elderly: mechanisms and prevention strategies. Consult Pharm 2014;29(6):413-7.

35. Venegas Sanabria LC, Barbosa Balaquera S, Suarez Acosta AM, García Peña ÁA, Cano Gutiérrez CA. Uso de estatinas y riesgo de caídas en ancianos: revisión sistemática de la literatura. Rev Esp Geriatr Gerontol 2017;52(6):317-21. doi: 10.1016/j.regg.2017.03.005

36. Enwonwu KG. Factors associated with orthostatic hypotension $\mathrm{n}$ the elderly In Anambra State. J Med Biomed Appl Sci 2018;6(10):173-80. doi: http://doi.wiley. com/10.1111/jgs.15732.

37. Bouaziz W, Vogel T, Schmitt E, Kaltenbach G, Geny B, Lang PO. Health benefits of aerobic training programs in adults aged 70 and over: a systematic review. Arch Gerontol Geriatr 
2017;69:110-27. doi: 10.1016/j.archger.2016.10.012

38. Güler-Yüksel M, Hoes JN, Bultink IEM, Lems WF. Glucocorticoids, Inflammation and Bone. Calcif Tissue Int 2018;102(5):592-606. doi: 10.1007/s00223-017-0335-7
39. Heffler E, Madeira LNG, Ferrando M. Inhaled Corticosteroids Safety and Adverse Effects in Patients with Asthma. J Allergy Clin Immunol Pract 2018;6(3):776-81. doi: 10.1016/j. jaip.2018.01.025 